\title{
131. 伝音系奇形耳に関する胎生学的研究
}

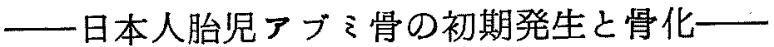

$\begin{array}{rrrr}\text { 増 田 } & \text { 游・大 } & \text { 島 昭 } 夫 \\ \text { 。遠 藤 洋 一・近 藤 }\end{array}$

\section{研 究目的}

近年耳科手術学の進步により，中耳伝音機構への直 接の手術操作が可能となり，今まで見塔てられていた 先天性伝音系聴器奇形患者の聴力障害を幼児期に手術 的に改善し，言語習得の道を開くととが可能となつた。 聴器の奇形病態を正確に把握し，手術操作を効果的に 行なうためには，ヒト聴器の正常発育史を詳紐に知る ことが必要となる，乙の目的の下にわれわれは，本邦 人胎児を用いてその聴器の発生を観察してきたが，こ こでは主にアブミ骨について述へた。

\section{研 究 方 法}

胎生第 8 週より 32 週までの胎児25体を用い，第11週 までのちのについては，固定後パラフィンに包埋，第 13週以後のちのは, 固定・脱灰後ツエルロイシンに包 埋，それぞれ連続切片とし，ヘマトキシリン・エオシ ンで染色し観察した。

\section{成}

\section{綪}

(1) 胎生初期一胎生第 8 週には，ツチ骨，キヌタ骨 は一つの凝集塊として認められ，メッケル氏軟骨と一 連である．胎生第 9 週にはアブミ骨はリング状を呈し， 閉鎖孔をアブミ骨動脈がつらぬく，胎生第10週には， ッチ骨・キヌタ骨・アブミ骨は一つつつの凝集をなす. 胎生第11週では，リング状のアブミ骨はキヌタ骨と接 しているが，関節としては完成していない。アブミ骨 の前庭側，すなわち Lamina stapedis と otic capsule の前庭空緣とは同じ原基からできろが， アブミ 骨底の中耳側疽および脚は，それらとは異なる原基よ りできる、また，アブミ骨とライハート氏軟骨は結び ついているが，両者が異なる原基から異なる時期に発 生した証扰はなかつた。

(2) 胎生中期および後期一胎生13週では，アブミ骨 はリング状を呈し、ッチ骨・キヌタ骨はほほ成人の形
に等しいが、いずれも赖骨のままである.胎生 17 週に なると、ツチ骨の䫓部、キヌタ骨長脚の上部に骨化点 が現われるが，アブミ骨はまだ軟骨である．胎生第19 週に初めてアブミ骨後脚基部に骨化点が見られる.胎 生第21週には，アブミ骨は前後脚とも骨化し骨娟腔の 形成がみられるが, 頭部および底の前庭側は未骨化で ある. 同じ第21週でも別の胎児では前脚の上半分が未 骨化のまま残つていた，胎生第25週になると，アブミ 骨は頭部のキヌタ骨との関節面, 底の前庭空縁に未骨 化部を残すのみで残りの部分は骨化し，閉鎖孔縁では 骨の破壊がはしまつている．胎生32週ではアブミ骨は 頭部関節面のみ軟骨性であり，閉鎖孔縁は骨の破㙏吸 収がすすみ，脚はトイ状になりつつあろ。とのとき， 顔面神経管水平部鼓室側では, 中央部に末骨化部分を 残す。

結垔

胎生第 8 週より第32週までの胎巟25体のアブミ骨を 観察しつぎの結果をえた。

(1) ツチ骨・キヌタ骨は同一原基から，また，アブ ミ骨はこれと異なる原基から発生する。

(2) 胎生第 9 週には, アブミ骨はリング状を呈する. このとき，閉鎖孔をアブミ骨動脈が貫いている，との アブミ骨動脈は胎生令がすすむと消失する.

(3) アブミ骨底の前庭側と otic capsule の前庭空 縁は同じ原基で，アブミ骨脚とは原基を異にする。

(4) アブミ骨の骨化は,ッチ骨・キヌタ骨にやや幄 れ，胎生第19週にはしまり，21週目には頭部と底の前 庭側を除いて骨化している。

(5)アブミ骨閉鎖孔縁の骨破壊吸収は，胎生第25週 頃はじまり，32週にはアブミ骨脚は外方に凸のトィ状 を呈する. 


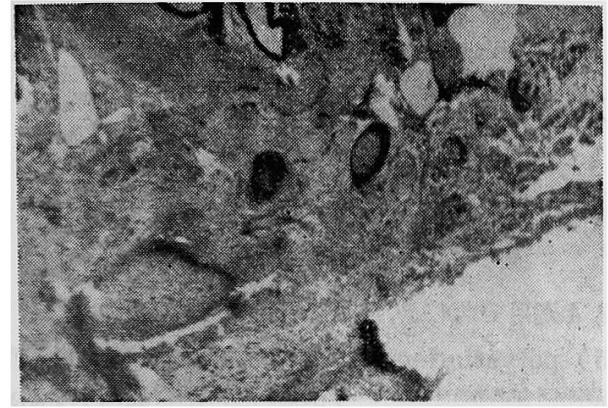

写真 1 胎生第10週



写真2 胎生第10週

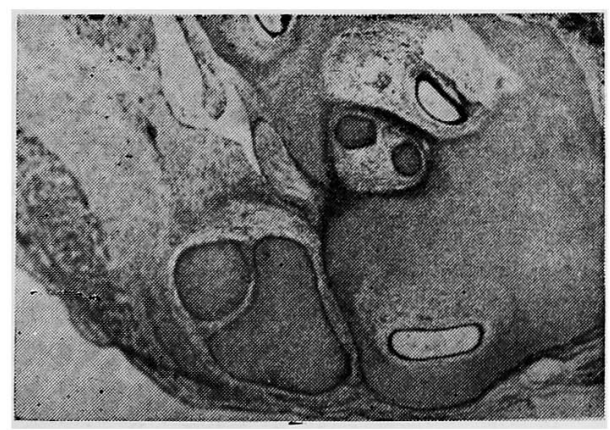

写真 3 胎生第11週

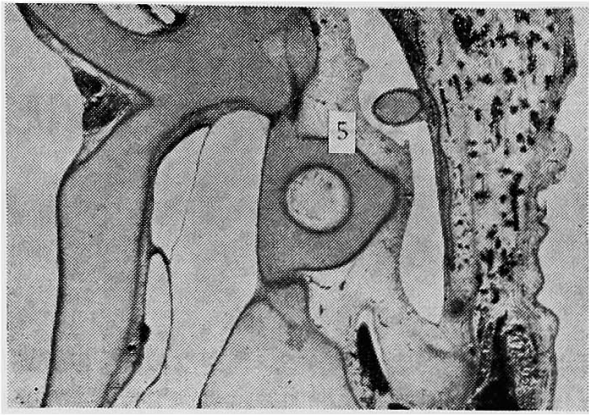

写真 4 胎生第13週



写真 5 胎生第19週

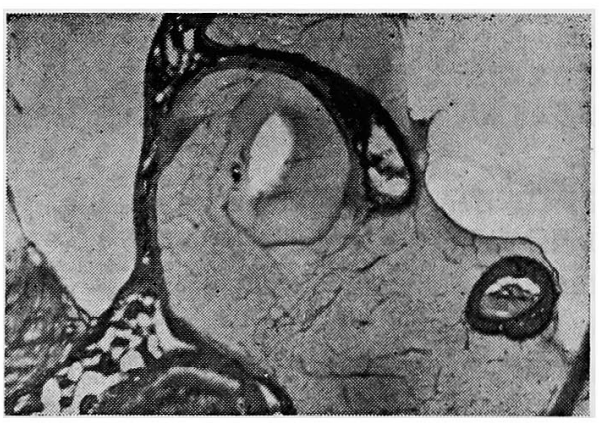

写真 6 胎生第32週

写真 説 明
1：ッチ骨
2：キヌタ骨
3 : ライハート氏軟骨
4 : 顔面神程
5：アブミ骨
6 : Interhyale 